\title{
Pohjoiset taajamapuut
}

\author{
Leena Lindén ${ }^{1)}$, Olavi Junttila ${ }^{2)}$ ja Virpi Mustiala ${ }^{3)}$ \\ ${ }^{1)}$ Soveltavan biologian laitos, PL 27,00014 Helsingin yliopisto, leena.linden@helsinki.fi \\ ${ }^{2}$ Soveltavan biologian laitos, PL 27,00014 Helsingin yliopisto, olavi.junttila@helsinki.fi \\ 3)virpi.mustiala@helsinki.fi
}

\section{Johdanto}

Puut ovat taajamakasvillisuuden näkyvin, pitkäikäisin ja arvokkain osa. Puiden avulla voidaan parantaa taajamaympäristöjen laatua, lisätä taajamien viihtyisyyttä ja vaikuttaa kaupunkikuvaan. Taajamapuilla on myös huomattava esteettinen ja elämyksellinen merkitys.

Pohjoisen ilmaston vuoksi Suomessa voidaan käyttää vain harvoja ulkomaisia taajamapuulajeja, lajikkeita ja viljelykantoja. Toistaiseksi maassamme on tehty hyvin vähän viherrakentamisen puulajien jalostusta tai valintaa; taimimateriaalin heikko geneettinen laatu on yksi taajamapuidemme suurimmista ongelmista. Tämän tutkimuksen tavoitteena oli osoittaa entistä parempia puualkuperiä, -lajikkeita ja siemen-lähteitä taimistoviljelyn lähtömateriaaliksi ja viherrakentamisen käyttöön. Taustalla oli pyrkimys saattaa alulle taajamapuiden jalostus maassamme.

Tutkimus toteutettiin vuosina 2001-2003 Helsingin yliopiston soveltavan biologian laitoksella, läheisessä yhteistyössä puiden tuottajien ja käyttäjien kanssa. Sen päärahoittajat olivat ympäristö- sekä maa- ja metsätalousministeriö ja Helsingin kaupunki. Tutkimus oli osa "Kaupunkipuut" hankekokonaisuutta, jossa kehitetään tietotaitoa ja sovelluksia kaupunkipuiden hoitoon ja viheralueiden rakentamiseen.

\section{Aineisto ja menetelmät}

Tutkimus jakautui viiteen tehtäväkokonaisuuteen:

\section{Lajisto- ja viljelykantaselvitys}

Hyvistä kotimaisista taajamapuiden lisäyslähteistä kerättiin tietoja haastatteluiden, kirjallisuuden ja kyselyiden sekä KESKAS- ja metsägeneettisten rekisterien avulla. Näitä tietoja tarkistettiin maastokäynneillä. Helsingin arvokkaita puutaksoneja inventoitiin rakennusviraston erillisrahoituksella ja Suomea ilmastollisesti vastaavilla alueilla käytössä olevista taksoneista haettiin tietoja kirjallisuudesta ja tietokannoista. Lupaavien ulkomaisten lajien ja lajikkeiden menestymistä meillä arvioitiin puulajikokoelmissa ja kasvitieteellisissä puutarhoissa.

\section{Lehmustutkimus}

Lehmukset (Tilia sp.) kuuluvat Etelä-Suomen taajamien suosituimpiin puisto- ja katupuihin. Uusissa istutuksissa käytetään yleensä joko siivosenlehmukseksi nimettyä puistolehmuskloonia (Tilia $\times$ vulgaris 'Siivonen') tai jotakin nimeämätöntä lehmuskantaa. Lehmuksista etsittiin viljeltäviksi uusia taksoneja ja kasvutavaltaan erityyppisiä klooneja tuhoriskien vähentämiseksi ja monimuotoisuuden lisäämiseksi. Lisäksi pyrittiin varmistamaan lehmusten lajinmääritystä morfologisia ja kemiallisia tunnuksia käyttäen.

Tutkimuksessa inventoitiin yli 3000 Helsingin vanhoissa puistoissa ja kujanteissa kasvavaa lehmusta. Helsingissä ja muualla maassa kasvavien lehmusten joukosta valittiin kuusi uutta kloonia lisättäviksi. Näistä viiden ja kymmenen muun lehmuskloonin taksonomista asemaa selvitettiin isoentsyymianalyysien avulla sekä analysoimalla yli 50:tä lehtien, kukkien, kukintojen ja hedelmien morfologiaan liittyvää tunnuslukua. Aineiston perusteella tutkittiin myös lehmusten sukulaisuussuhteita ja morfologisten tunnusten luotettavuutta lehmusten määrittämisessä.

\section{Taajamapuurekisteri}

Lajisto- ja viljelykantaselvityksen sekä lehmustutkimuksen tiedot koottiin taajamapuurekisteriin. Rekisteriin tallennettiin kuvaus kustakin puutaksonista tai lisäyslähteestä, sen erityisominaisuuksista ja kasvupaikasta sekä tieto siitä, onko kanta jo viljelyssä.

\section{Kantavertailukokeet}

Helsinkiin ja Iisalmeen perustettiin vuonna 2002 tärkeimpien siemenistä lisättävien taajamapuulajien [tammi (Quercus robur L.), metsävaahtera (Acer platanoides L.), suomen- ja ruotsinpihlaja (Sorbus hybrida L. ja S. intermedia (Ehrh.) Pers. ), kynä- ja vuorijalava (Ulmus laevis Pallas ja U. glabra Hudson) sekä metsälehmus (Tilia cordata Miller)] taimistokantoja vertailevat kokeet. Molemmissa kokeissa on kustakin puulajista verrattavina kahdesta seitsemään taimistoilla käytössä olevaa lisäyslähdettä. Puut olivat istutettaessa yhdestä neljään vuoden ikäisiä. Puiden kasvua, tuleentumista ja talvehtimista mitataan 
vuosittain. Samalla selvitetään eri kantojen hoidontarve ja seurataan tautien ja tuholaisten esiintymistä. Kokeita jatketaan vuoteen 2012 asti.

Lehmustutkimuksessa valittuja kuutta kloonia ja siivosenlehmusta lisättiin varttamalla viidellä kotimaisella, eri puolilla maata sijaitsevalla taimistolla. Taimistot jatkavat puiden kasvatusta seuraavien kolmen vuoden ajan. Taimistoviljelyn aikana saadut kokemukset kloonien kasvusta ja menestymisestä vaihtelevissa maaperä- ja ilmasto-oloissa kootaan yhteen. Vuonna 2007 taimet istutetaan vertaileviin kokeisiin vähintään kahdelle paikkakunnalle maan eri osiin.

\section{Lisäysmateriaalihuollon kehittäminen}

Suomessa kestäviksi osoittautuneista salavista (Salix sp.) valittiin yhteistyössä Keski-Suomen maaseutukeskuksessa toimivan Pekka Ilénin kanssa 30 kloonia lisättäviksi. Salavat lisättiin pistokkaista soveltavan biologian laitoksella ja ne istutetaan vuonna 2004 Viikin arboretumiin. Tulevaisuudessa nämä puut sopivat käytettäviksi lisäyslähteenä, josta taimistoviljelijät voivat saada alkuperältään tunnettua, aitoa pistokasmateriaalia.

Metsävaahteran kasvullinen lisääminen varttamalla on Suomessa hankalaa ja kallista lyhyen kasvu-kautemme takia. Pohjoiset taajamapuut -hankkeessa pyrittiin kehittämään toimivaa mikrolisäysmenetelmää vaahteralle yhteistyössä Fin Taimi Oy:n kanssa. Mikrolisäyskokeissa tutkittiin kahden eri sytokiniinin ja aloitussolukkotyypin vaikutusta vahteran versontuottoon.

\section{Tulokset ja tulosten tarkastelu Lajisto- ja viljelykantaselvitys}

Suomessa luonnonvaraisten tai meillä jo pitkään viljeltyjen puiden joukosta valittiin rekisteröitäviksi kaikkiaan noin 160 puuyksilöä tai siemenlähdettä. Erikoisimpia selvityksessä löytyneitä puita ovat Turussa kasvava keltalehtinen metsävaahtera, Tampereelta tavatut hopealehmukset (Tilia tomentosa Moench) (Lindén 2003) ja salolaiset visakoivut [Betula pendula var. carelica (Mercklin) Hämet-Ahti] "Teuvo" ja "Tuomo". Helsingistä rekisteröitiin noin 50 lehmus- ja 20 muuta puutaksonia (Mustiala 2003a ja 2003b). Kanadalaisista luonnonlajeista ja Ruotsissa käytössä olevasta taajamapuulajistosta valittiin 27 taksonia, joita voi suositella koeviljelyyn Suomessa (Numminen 2003).

\section{Lehmustutkimus}

Helsingissä inventoiduista lehmuksista $58 \%$ määritettiin puistolehmuksiksi (Tilia $\times$ vulgaris Hayne). Toiseksi yleisin laji oli isolehtilehmus (T. platyphyllos Scop.), jonka osuus tutkituista puista oli $18 \%$. Metsälehmuksia oli $7 \%$ ja kriminlehmuksia (T. euchlora C. Koch) $1 \%$ tutkituista puista. Lehmusten lajinmääritys on varsin vaikeaa ja niinpä tässäkin selvityksessä vajaa viidesosa (17\%) puista jäi kokonaan vaille nimeä. Tunnistamatta jääneet lehmukset ovat Suomessa harvoin tavattuja lajeja tai tuttujen lehmuslajien alalajeja ja lajikkeita sekä nuoria tai huonokuntoisia puita, joiden nimeäminen on hankalaa. Lehmus-tutkimuksen Helsinkiä koskevasta osasta julkaistiin raportti (Mustiala 2003a), joka sisältää inventoinnin tulosten lisäksi tietoa lehmusten käytön historiasta Helsingissä ja eri puistojen ja katujaksojen lehmus-istutuksista.

Lehmusten määrittäminen morfologisten tunnusten perusteella edellyttää yleensä useiden tunnusten samanaikaista tarkastelua (Härkönen 2002). Suomalaisesta aineistosta tehdyt mittaukset vahvistivat, että määrityksen luotettavuus on sitä parempi, mitä useampaa tunnusta tarkastellaan. Selkeärajaisia, taksoni-tyypillisiä morfologisia tunnuksia lehmuksissa on vähän. Metsäntutkimuslaitoksella metsälehmusta varten kehitetty isoentsyymianalyysimenetelmä toimi hyvin myös muilla saman suvun taksoneilla: lehmusnäytteistä saatiin 4-5 tulkintakelpoista tsymogrammia, joiden perusteella entsyymejä koodaavissa geenilokuksissa havaittiin muuntelua. Tutkitut 15 lehmuskloonia voitiin määrittää vähintään lajitasolla morfologisten ja kemiallisten tunnusten perusteella.

\section{Taajamapuurekisteri}

Rekisterissä on nyt tiedot noin 160:stä puusta tai siemenlähteestä. Rekisteröityjen lisäyslähteiden joukossa on eniten lehmuksia (64 kpl). Puumaisista pajuista eli salavista on rekisteröity 24 , metsävaahterasta 14, metsä-tammesta ja pihlajan suvusta kummastakin seitsemän lupaavaa lisäyslähdettä.

\section{Lisäysmateriaalihuollon kehittäminen}

Metsävaahteran solukkoviljelykokeissa onnistuttiin lisäämään versontuottoa, mutta ei versojen pituuskasvua. Kasvatusalustan hormonikoostumuksen optimointi ja toimivan mikrolisäysmenetelmän aikaansaaminen edellyttävät vielä paljon lisätutkimuksia. Vaahteran, niin kuin useiden muidenkin puulajien, mikrolisäyksessä esiintyvät ongelmat näyttävät ainakin osittain liittyvän myös kasvupisteiden solukoissa yksilönkehityksen aikana tapahtuviin muutoksiin. 


\section{Johtopäätökset}

Tutkimuksen tulokset osoittavat, että taajamapuidemme valikoimaa voidaan lisätä ja laatua parantaa suhteellisen vähäisin resurssein. Kotimaisen taimistoviljelyn lähtöaineiston parantamiseksi olisi tehtävä yksinkertaista valintajalostusta, järjestettävä vertailevia kokeita ja saatettava parhaat kotimaiset lisäyslähteet viljelijöiden käyttöön. Taimimateriaalin geneettisen laadun parantaminen johtaisi säästöihin istutusten perustamis- ja hoitokuluissa ja lisäisi taajamapuidemme monimuotoisuutta, terveyttä ja elinikää. Ongelmal-lista on, että puita koskevan jalostustyön tulokset ovat nähtävissä vasta vuosien päästä. Taajamapuiden jalostus ei sovi lyhytkestoisella hankerahoituksella toteutettavaksi, vaan se olisi saatava osaksi jonkin tutkimuslaitoksen pitkäjänteistä toimintaa.

\section{Kirjallisuus}

Härkönen, J. 2002. Suomessa viljeltyjen lehmustaksonien morfologiset ja fenologiset tuntomerkit. Puutarhatieteen kandidaatintutkielma. Helsingin yliopisto, soveltavan biologian laitos. 41 s. +4 liit.

Lindén, L. 2003. Hopealehmus (Tilia tomentosa Moench) Tampereella. Sorbifolia 34: 140-142.

Mustiala, V. 2003a. Helsingin lehmukset. Pohjoiset taajamapuut -tutkimuksen osaraportti. Helsingin kaupungin rakennusviraston julkaisut 2003:5. 68 s. +9 liit.

Mustiala, V. 2003b. Helsingin lehtipuut. Pohjoiset taajamapuut -tutkimuksen osaraportti. (Käsikirjoitus.)

Numminen, S. 2003. Uusia ulkomaisia puutaksoneja viherrakentamiseen. Puutarhatieteen

kandidaatintutkielma. Helsingin yliopisto, soveltavan biologian laitos. (Käsikirjoitus.)

Riikonen, A. 2003. Metsävaahteran (Acer platanoides) mikrolisäys. Puutarhatieteen kandidaatintutkielma. Helsingin yliopisto, soveltavan biologian laitos. $40 \mathrm{~s}$. 